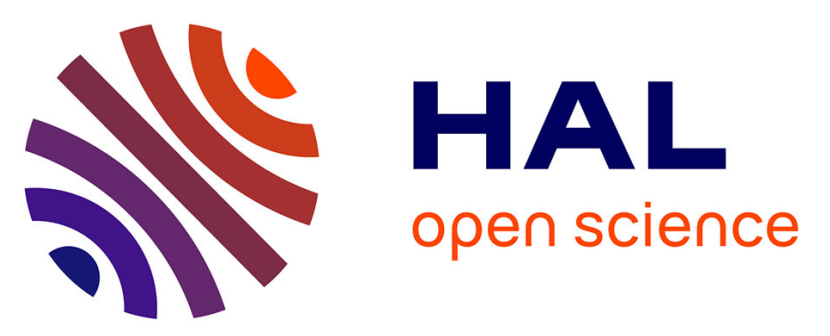

\title{
PbO SPECTROSCOPY AND STUDIES OF THE INTERACTION OF SINGLET MOLECULAR OXYGEN WITH LEAD ATOMS BY LASER-INDUCED FLUORESCENCE AND BY HIGH-RESOLUTION FOURIER TRANSFORM SPECTROSCOPY
}

J. Bachar, R. Bacis, S. Churassy, F. Martin, S. Rosenwaks, G. Taïeb, J. Vergès

\section{- To cite this version:}

J. Bachar, R. Bacis, S. Churassy, F. Martin, S. Rosenwaks, et al.. PbO SPECTROSCOPY AND STUDIES OF THE INTERACTION OF SINGLET MOLECULAR OXYGEN WITH LEAD ATOMS BY LASER-INDUCED FLUORESCENCE AND BY HIGH-RESOLUTION FOURIER TRANSFORM SPECTROSCOPY. Journal de Physique Colloques, 1987, 48 (C7), pp.C7-381-C7-383. 10.1051/jphyscol:1987791 . jpa-00227096

\section{HAL Id: jpa-00227096 https://hal.science/jpa-00227096}

Submitted on 1 Jan 1987

HAL is a multi-disciplinary open access archive for the deposit and dissemination of scientific research documents, whether they are published or not. The documents may come from teaching and research institutions in France or abroad, or from public or private research centers.
L'archive ouverte pluridisciplinaire HAL, est destinée au dépôt et à la diffusion de documents scientifiques de niveau recherche, publiés ou non, émanant des établissements d'enseignement et de recherche français ou étrangers, des laboratoires publics ou privés. 
PbO SPECTROSCOPY AND STUDIES OF THE INTERACTION OF SINGLET MOLECULAR OXYGEN WITH LEAD ATOMS BY LASER-INDUCED FLUORESCENCE AND BY HIGHRESOLUTION FOURIER TRANSFORM SPECTROSCOPY

J. BACHAR, R. BACIS*, S. CHURASSY*, F. MARTIN*, S. ROSENWAKS, G. TÄ̈EB** and J. VERGÈs***

Ben Gurion University, Physics Department, PO BOx 653, IL-Beer Sheva 84105. Israel

"Laboratoire de spectrometrie Ionique et Moléculaire, (CNRS UA171 et Greco Celphyra). Université Lyon-I, 43, Bd du 11 Novembre 1918, F-69622 villeurbanne Cedex, France

* Laboratoire de photophysique Moléculaire, Université Paris-Sud, Bât. 213, F-91405 Orsay Cedex, France

*** Laboratoire Aimé cotton, CNRS II, Bât. 505, F-91405 orsay Cedex, France

The ' $\Delta_{8}$ statcof $\mathrm{O}_{2} \mathrm{l}=\mathrm{O}_{2}{ }^{\prime} \mathrm{I}$ has an extremely large radiattve lifetime $(-1$ hour $)$ and is quenched with a very low effictency by collisions with various types of wall.The success of pumping the foctine atom by $\mathrm{O}_{2}\left[{ }^{1} \Delta_{8}\right]$ in the Chemical Oxygen-lodine Laser has led to the examination of tts action on vanious atoms (1), and in particular on leaci, because the lowest excited state ${ }^{3} \mathrm{P}_{1}$ is in quasi-resonance with $\mathrm{O}_{2}\left[^{2} \Delta_{2}\right.$ l ( fig 1).

The mibing of molecular axygen and lead atoms in their ground states $\left(\mathrm{O}_{2} \beta_{\Sigma} \Sigma_{8}\right)$ and $\mathrm{Pb} \beta \mathrm{P}$ ) does not produce a reaction. With $\left.\mathrm{O}_{2} \mathrm{l}^{1} \Delta_{2}\right]$ a rather bright name appears. The

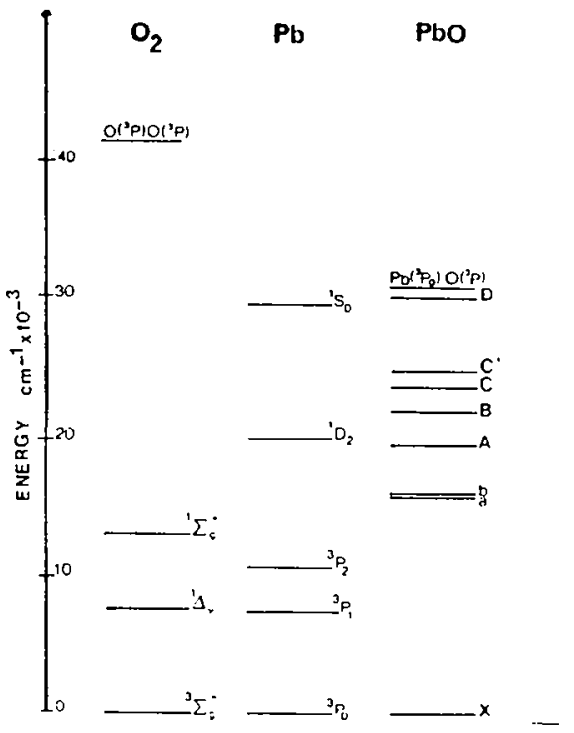

Eigure 1 Energy levels of $\mathrm{Pb}_{1} \mathrm{O}_{2}$ and $\mathrm{PbO}$

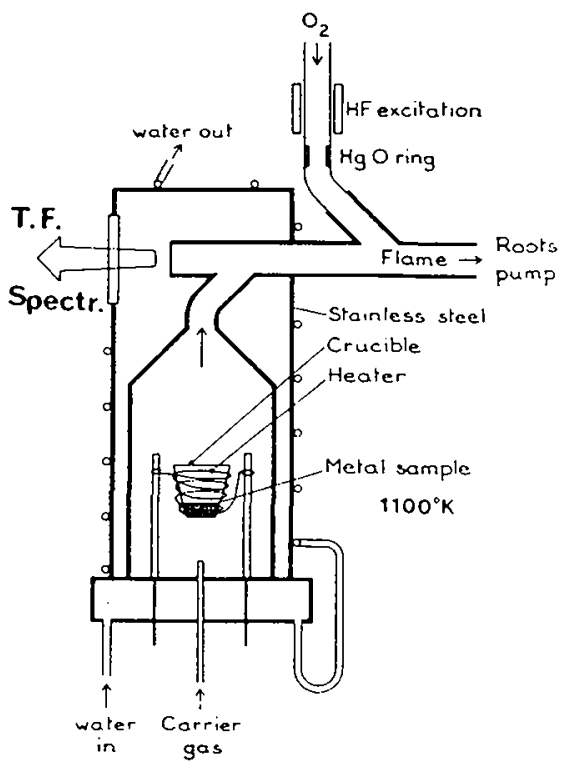

Figure? Experimental arrangement. 
emission comes matnly from the lowest excited states of $\mathrm{Pb}$ and $\mathrm{PbO}$. The abundant formation of $\mathrm{PbO}$ is a competing reaction which tends to hinder the acheivement of population inversion in $\mathrm{Pb}$ atoms : it is therefore desirable to eliminate the formation of $\mathrm{PbO}$, and hence we need to know and understand the reactions involved.

We have undertaken a high resolution spectroscopic study of the $\mathrm{O}_{2}\left[\Delta_{2}\right] \cdot \mathrm{Pb}$ flame in onder to obtain new spectroscopic data on the $\mathrm{POO}$ molecule, and to determine the excited state pupulations in the steady state regime of the flame. A bright and stable flame was created with a Broida-type oven (fig 2).

High resolution liourier transform spectra were obtained using natural $\mathrm{Pb}$ ( see fig 3 ) and

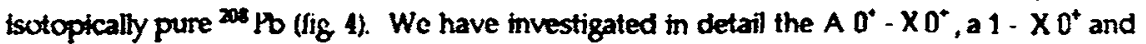
$\mathrm{B} 1-\mathrm{XO}^{+}$transtions of $\mathrm{PbO}$ produced in the reaction of $\mathrm{O}_{2}\left[\mathrm{P}_{2}\right]$ with $\mathrm{Pb}$.

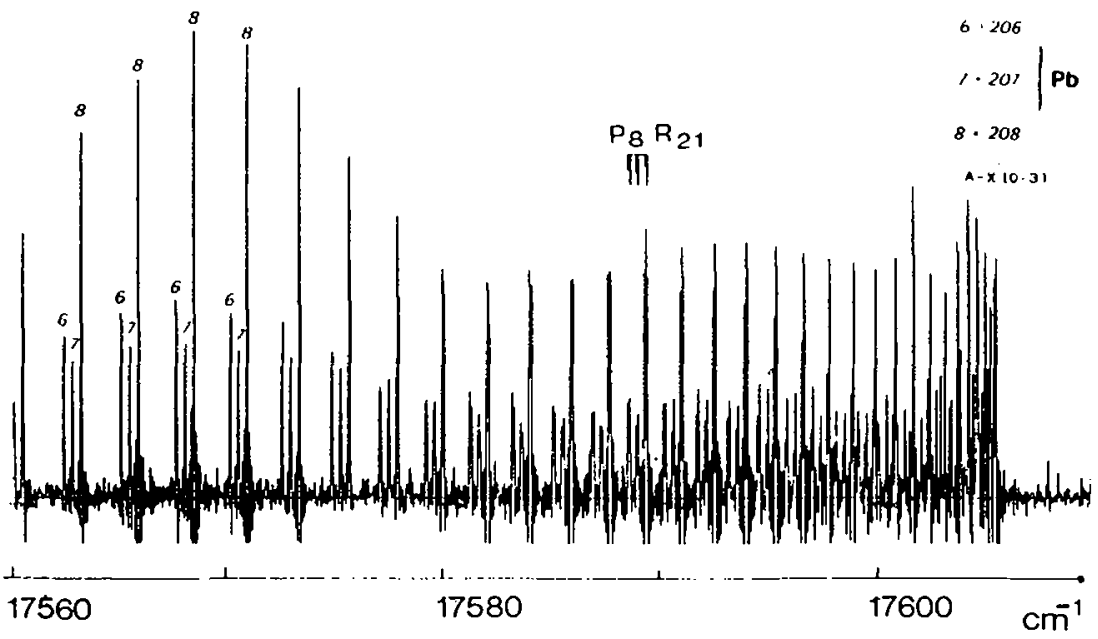

Eigure $3 \mathrm{An}^{+} \mathrm{XO}^{+}(0.3)$ band head of natural PbO. The intensities are in agreement with the natural abundances: ${ }^{200} \mathrm{~Pb} 523 \%$, $207 \mathrm{~Pb} 22.6 \%$ and ${ }^{206} \mathrm{~Pb} 23.6 \%$. Recorded in 2 hours

The traditional spectrosoopic constants characterizing the $A$ and $X$ states have been preciscly determined for $\mathrm{PbO}$ (Table 1). There were too many superpostions in the natural POO spectra to obtain accurate data for the two other isotopes. Nevertheless, the classical Dunham isotope relations enable their line positions to be calculated from the ${ }^{208}$ PhO constants. We have fuund that the non blended lines in the natural PhO spectrum are indeed recalculated to within the expertmental accuracy (error $\sim 0.005-0.010 \mathrm{~cm}^{-1}$ ).

Table 1 Equilibrium constants $\left(\mathrm{cm}^{-1}\right)$ for the $\mathrm{XO}^{+}$and $\mathrm{AO}^{+}$states of ${ }^{208} \mathrm{PbO}$.

The $\omega_{e} x_{e}$ parameter for the $A 0^{+}$state is observed to be negative, explaining the variations amongst the values of $\omega_{e} x_{e}$ given by different authors (2).

$X$ State

$\begin{array}{ll}\omega_{e} & 720.9580(36) \\ \omega_{e} x_{e} & 3.5161(11) \\ \mathrm{r}_{e} & 1.9218 \AA \\ \mathrm{B}_{\mathrm{e}} & 0.3073121(42) \\ \alpha_{\mathrm{e}} & 0.19084(75) \times 10^{-2}\end{array}$

A State

442.897(37)

$-0.123(25)$

$2.0950 \mathrm{~A}$

$0.258596(19)$

$0.1270(45) \times 10^{-2}$ 
The relative intensities of the rotational lines are well-determined in the $200 \mathrm{PbC}$ spectra. They show that the significantly populated vibrational levels of the $\mathrm{AO}^{+}$state have a Boltrmann rotational distribution, comesponding to a temperature of $860 \mathrm{~K}$ (fi\& 5). The comparison of the intenstties between different bands show that the vibralional populations are in the ratio of the intensities: $\operatorname{Int}(v=0)=1.0, \operatorname{Int}(v 1)=1.2$ and $\operatorname{Int}(v=2)=$ 0.7. There is a small population inversion between $v=1$ and $v: 0$ in the $A$ state. The comparison of the bands' intensities, recorted at low resolution gave the same results. Simple multi-step processes possibly involvect in the reaction cannot explain this inversion. Further investigations of the name are now in progress.

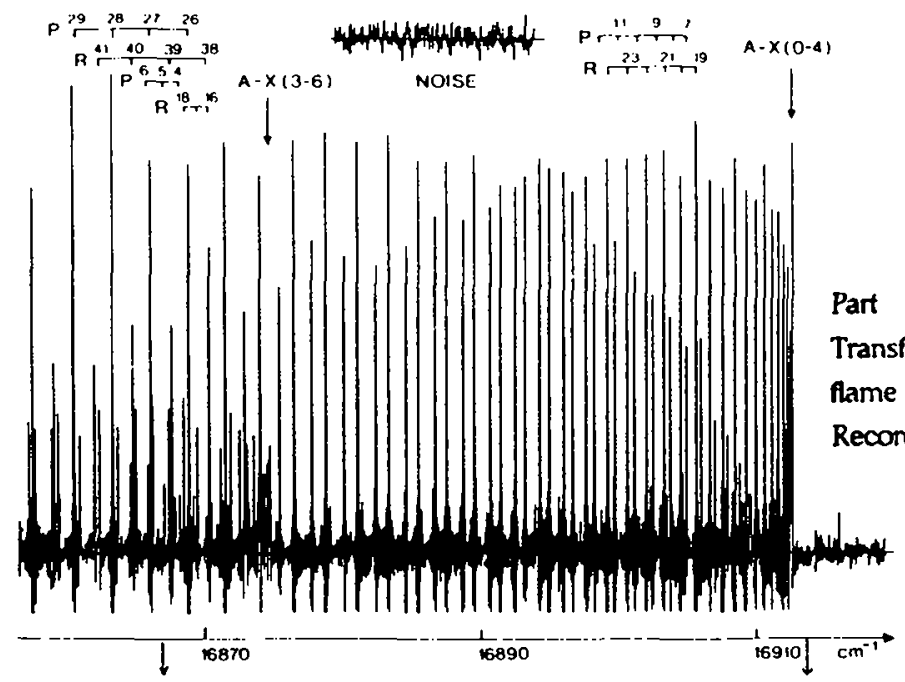

\section{Eigure 4}

Part of the non-apodised Fourier Transform recurd of the ${ }^{208} \mathrm{~Pb}-\mathrm{O}_{2}\left[{ }^{1} \Delta_{\mathrm{g}}\right]$ flame at high resolution $(0.044 \mathrm{~cm}$ ). Recorded in 2 hours.

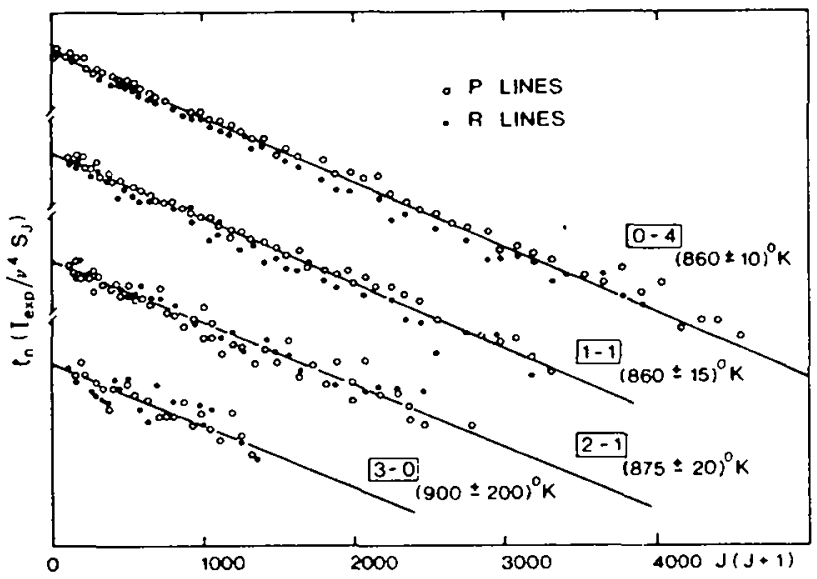

\section{Eigure 5}

Detcrmination of the rolational temperature in the vibrational levels of the A state from the $\mathrm{PbO}$ spectrum.

\section{References.}

(1) S. Rusenwacks and J. Bachar Inst. Phys. Conf. Ser. Z2, 137 (1985).

(2) K P Huber and r. Herzberg "Molecular Specira and Molectlar Structure, vol 4 Constants of Niafomic Molecules "(Van Nostrand- Rheinhold, New-York, 1979 ) page 526. 